Studies in African Linguistics

Volume 36, Number 1, 2007

\title{
THE PRONOMINAL SYSTEM OF ODUAL ${ }^{*}$
}

\author{
Ethelbert E. Kari \\ University of Port Harcourt
}

\begin{abstract}
This paper discusses the pronominal system of Odual, which has five subsets of pronouns: personal, reflexive, interrogative, demonstrative, and indefinite. A noteworthy feature of the system is the distinction between inclusive and exclusive first person plural personal pronouns. Reflexivity is marked by a noun meaning 'self' plus a possessive pronoun, the noun varying in form depending on the singularity or plurality of the antecedent. It is noted that tense/aspect markers in Odual show limited agreement for person and number, and in some cases they do not have distinct forms to reflect the differences in the forms of pronouns occasioned by differences in person and number. Also noted is the fact that the basic word order in Odual simple clauses is SVO, and that word order in NPs to a large extent is typologically consistent with the basic word order, as many of the pronouns that function as modifiers follow the noun they modify.
\end{abstract}

\section{Introduction.}

Onu Odual [onu odúal] (The Odual Language), often shortened to Odual [ódúál] is a largely under-studied Central Delta language spoken by the Odual community in Abua-Odual Local Government Area of Rivers State of Nigeria. The Odual community is divided into three major groups, Adibaam [ádíbámm], Arughunya [aruүuna] and Abureni [ə6uréni] groups. The Adibaam group comprises Adada

\footnotetext{
* I am immensely grateful to Mr. Isaiah Edighotu, a native speaker of the Adibaam [ədibəəm] dialect of Odual, for providing the data needed for this paper, and for sharing his knowledge of Odual with me. I am also grateful to David Odden and an anonymous SAL reviewer for their detailed and insightful comments, which have helped to improve the quality of this paper. I accept responsibility for any errors that remain.
} 


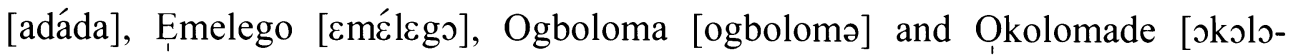
məde]; the Arughunya group comprises Ekunuga [ekúnúgə], Anyu [anu], Emaarikpoko [عmaáríkpoks], Obedum [obedúm] and Odau [odáu], while the Abureni group comprises A,kani [akanI] Amuruto [amuruto] and Emago-Kugbo [عmagókugbóo] (cf. Gardner et al. 1974 and Comson 1987). Comson (1987: viii), citing the Rivers State of Nigeria Ministry of Economic Development and Planning (1983), puts the population of Odual at 30,028.'

The Odual Clan is bounded in the east by Abua villages of Ogbema, Arukwo, Ogbogolo, in the west by Oloibiri, Amurukeni in Ogbia (in Bayelsa State of Nigeria), in the north by Oruma, Ibelebiri, Kolo (also in Ogbia), and in the south by Nembe town of Oluasiri, Bassambiri, Ekpoma, Ogbolomabiri (also in Bayelsa State of Nigeria), etc. (Comson 1987: vii). Odual is not spoken by all the communities that make up the Odual Clan. The communities that do not speak Odual are those that belong to the Abureni group. These communities speak Kugbo, a Delta Cross language that is coordinate with Odual (Comson 1987: xii). In addition to Odual, some speakers in the Adibaam group also understand and speak Abuan, Kugbo, Nembe, Kalabari and Ogbia (Kolo Creek), some speakers in the Arughunya group also understand and speak Ogbia, while some speakers in the Abureni group also understand and speak Ogbia, Nembe and Kalabari. Speakers of the Odual Language call themselves Ikpetemonu Odual [Ikp\&temonu odúal], meaning 'speakers of the Odual language.' A speaker of this language is called Okpetemonu Odual [okpetemonu odúal].

Odual is coordinate with other Central Delta languages such as Abuan, Kugbo, Mini, Obulom, Ogbia, Ogbogolo and Ogbronuagum (Faraclas 1989: 381). These languages with which Odual is coordinate are also spoken in Rivers State of Nigeria, except Ogbia, which is spoken in Bayelsa State of Nigeria. There is a dearth of scholarly linguistic literature on these languages in comparison with languages such as Degema, Kalabari, Obolo, and Izon. The major linguistic study on Odual is Comson (1987), which provides a detailed description of the phonology of this language. Other materials on Odual include Gardner et al. (1974), Gardner (1975), Kari (2006) and Madumere (2006).

The paper discusses the pronominal system of Odual. It recognizes and discusses five subsets of pronouns: personal, reflexive, interrogative, demonstrative, and indefinite pronouns. The paper also discusses one of the interesting features of the pronominal system of Odual, which is the distinction between inclusive and

Information about how many people speak Odual in what villages is not available at the time of writing this paper. 
exclusive first person plural personal pronouns. The inclusive/exclusive distinction is overtly expressed in the forms of the first person plural pronouns. The paper also discusses word order in Odual and examines how the order of the various pronouns reflects or diverges from the basic word order in simple clauses.

\section{The Vowel System of Odual. ${ }^{2}$}

Odual has twenty phonemic vowels (Comson 1987). Of this number, ten are single oral vowels $/ \mathrm{i}, \mathrm{I}, \mathrm{e}, \varepsilon, \mathrm{a}, \partial, \mathrm{\jmath}, \mathrm{o}, \mathrm{U}, \mathrm{u} /$, while ten are double ${ }^{3}$ oral vowels /ii, II, ee, $\varepsilon \varepsilon$, aa, əə, эว, оо, uU, uu/. These vowels are further divided into two sets, expanded $[+\mathrm{ATR}]^{4}$ and non-expanded [-ATR].

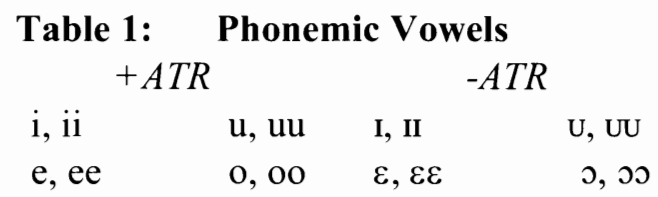

ə, әә $\quad \mathrm{a}$, aа

${ }^{2}$ We present the vowel system of Odual because of the phenomenon of vowel harmony, which is crucial in the selection of the correct forms of tense/aspect markers attached to the verb, for instance. There is no consonant harmony in the language.

${ }^{3}$ Double oral vowels are analyzed in this work as single syllables consisting of two moras. The Odual word ééná 'you (pl.)', for instance, is analyzed as two syllables consisting of three moras é.é.nó, while the word ezirá 'we (incl.)' is analyzed as consisting of three syllables and three moras e.zi.ró. Mutaka \& Tamanji (2000: 82) remark that “Although African languages are not known for a highly developed metrical structure, the notion of mora is still useful in accounting for example for the association of tone or the lengthening of a vowel."

${ }^{4}$ The following abbreviations are used in this paper: $1 \mathrm{sg} .=$ first person singular, $1 \mathrm{sgO}=$ first person singular object, $1 \mathrm{sgS}=$ first person singular subject, $2 \mathrm{sg}$. = second person singular, $2 \mathrm{sgO}=$ second person singular object, $2 \mathrm{sgS}=$ second person subject, $3 \mathrm{sg}$. = third person singular, $3 \mathrm{sgS}=$ third person singular subject, $1 \mathrm{pl} .=$ first person plural, $1 \mathrm{plS}=$ first person plural subject, $2 \mathrm{pl}$. $=$ second person plural, $2 \mathrm{plS}=$ second person plural subject, $3 \mathrm{pl}$. third person plural, $3 \mathrm{plS}=$ third person plural subject, $\mathrm{ATR}=$ advanced tongue root, $\mathrm{C}=$ consonant, $\mathrm{CERT}=$ certainty, DIST $=$ distal demonstrative, $\mathrm{EXCL} / \mathrm{excl} .=$ exclusive, $\mathrm{FOC}=$ focus marker, $\mathrm{FUT}=$ future, $\mathrm{INCL} /$ incl. $=$ inclusive, $\mathrm{NP}=$ noun phrase, $\mathrm{O}=$ object, $\mathrm{OM}=$ object marker, PST $=$ past, PLUR $=$ pluriactional, POSS $=$ possessive, PRES PERF $=$ present perfect, pl. = plural, $\mathrm{PROX}=$ proximal demonstrative, $\mathrm{S}=$ subject, $\mathrm{sg} .=$ singular, $\mathrm{V}=$ vowel/verb. 
The two sets of vowels do not co-occur in simple words in Odual as in [+ATR] ekpom 'heart', *ekpom, aəbədi 'iguana' *aabadi and [-ATR] odút $\eta^{w} \varepsilon$ 'hornbill (long-tailed)', * ${ }^{*}{ }^{\prime} \eta^{n '} \varepsilon$, osdoronú 'lip', *oodəronú. The starred forms are deviant forms because they consist of vowels drawn from both sets. There are, however, a few exceptional cases to which this widespread rule does not apply. Gardner et al. (1974: 9) note that, "there are a limited number of words, most of which contain the vowel 'e ' $(\varepsilon)$ (and $(e)$ ) in which both heavy [+ATR] and light [-ATR] vowels occur together so that there is no vowel harmony" (parentheses and brackets mine). The words áráá-kpés 'trouble' and ale-k' 'leg' are illustrative examples.

\section{Pronouns.}

Pronouns substitute for nouns and noun phrases. Five subsets of pronouns can be recognized in Odual. These subsets are personal, reflexive, interrogative, demonstrative, and indefinite pronouns. We shall discuss them one by one.

3.1. Personal pronouns. Odual distinguishes three types of personal pronouns, depending on the position and function of these pronouns in a sentence. The three types of personal pronouns are subject, object, and possessive pronouns. These pronouns encode in themselves grammatical categories such as person, number and case (cf. Ndimele 1996, Deterding \& Poedjosoedarmo 2001, and Börjars \& Burridge 2001). Odual does not make any gender distinction in its pronominal system.

There is a three-way person distinction in Odual personal pronouns. The language distinguishes first person, second person and third person. First person is used by the speaker to refer to himself or to a group which the speaker is a part of. Second person is used to refer to the hearer or to a group which the hearer is a part of. Third person is used to refer to person(s) or thing(s) excluding the speaker and hearer (cf. Lyons 1968: 276). Givón (1984: 354) uses the term 'non-

${ }^{5}$ There are two basic tones in Odual, low and high, plus a downstep. In this paper only the high and the downstep are marked. The high tone is marked ('), while the downstep is marked (б́'́) with an arrow pointing downwards between two high-toned moras. In general, the low tone is not marked for the sake of convenience. In this paper, tone is not marked in proper names. The Odual data in the paper are transcribed using phonetic symbols that have IPA values. The description is eclectic, meaning that the analysis adopted is not based on any particular linguistic theory. 
participant' to refer to the 'third' person. In respect of number in personal pronouns, the language distinguishes between singular and plural. Whereas singular refers to the concept of one, plural refers to the concept of more than one. The language also distinguishes three cases in personal pronouns. These are the subjective or nominative, objective or accusative and possessive or genitive cases.

An interesting and distinguishing feature of the pronominal system, especially as regards personal pronouns, is the distinction the language makes between inclusive and exclusive first person plural. This distinction, according to Givón (1984: 354), “...pertains to the hearer's inclusion in or exclusion from, the referential scope of 'we', either dual or plural. 'We-INCL' is thus 'we, including you,' and 'we-EXCL' is thus 'we, excluding you'" (cf. Lyons 1968: 277). The inclusive/exclusive distinction is overtly expressed in the forms of first person plural pronouns. The reason for the overt distinction in the forms of the first person plural pronouns is well expressed by Givón. According to him, "...inclusion/exclusion are not directly predictable from the speaker and hearer, they are potentially ambiguous in the speech situation, and it is thus only natural that they may require overt specification ('marking')" (Givón 1984: 355).

3.1.1. Subject pronouns. Subject pronouns occur before the verb, and function as the subject of a sentence. When these pronouns are pronounced in isolation, they have the forms given in Table 2:

\begin{tabular}{cccc} 
Table 2: & \multicolumn{3}{c}{ Forms of Subject Pronouns } \\
Singular & $1^{\text {st }}$ & áámi & 'I' \\
& $2^{\text {nd }}$ & átná & 'you' \\
& $3^{\text {rd }}$ & odí & 's/he/it' \\
& & & \\
Plural & $1^{\text {st }}$ & eziró & 'we' (incl.) \\
& & ézóór & 'we' (excl.) \\
& $2^{\text {nd }}$ & eenó & 'you' \\
& $3^{\text {rd }}$ & eedí & 'they'
\end{tabular}

Tonally, the first person singular and first person plural exclusive subject pronouns have a high tone pattern, i.e. all moras are high toned; the third person singular, first person plural inclusive and second and third person plural have the same tone pattern - low-high, while the second person singular subject pronoun has a high-downstepped-high tone pattern. Segmentally, all subject pronouns begin with a vowel. Whereas the first person singular, first person plural (inclusive 
and exclusive) and second and third person plural are trimoraic, the second and third person singular forms of these pronouns are bimoraic.

It is observed in (1) that all subject pronouns maintain their inherent tone patterns in sentences, except the ones that refer to first and second person singular and first person plural exclusive:

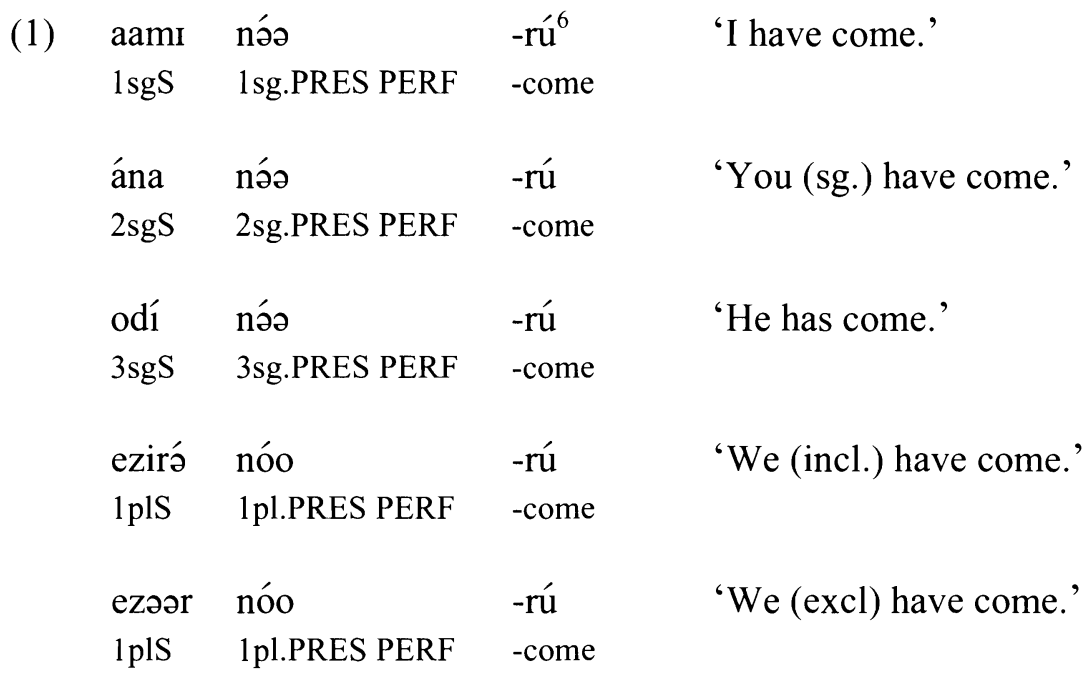

${ }^{6}$ The form of the present perfect marker is $n V V$-, which varies according to the number and person of the subject of the sentence. It is observed that the form nəa-is associated with first person, second person and third person singular subject; the form noo- is associated with first person (inclusive/exclusive) plural subject, while nee- is associated with second and third person plural subject. These forms are further determined by the quality of the vowel in the verb stem. The forms naz-, noo- and nee- occur with verb stem that contain [+ATR] vowels, while the forms $n a a-, n \supset 0$ - and $n \varepsilon \varepsilon$ - occur with verb stems that contain [-ATR] vowels.

Forms of other tense/aspect markers behave in a similar way. Tense/aspect markers in Odual show limited agreement for person and number, given that they do not have distinct forms to reflect the differences in the forms of pronouns occasioned by differences in person and number. For example, the form naz- in (1) is associated not only with first person singular subject but also with second person and third person singular subject. Similarly, the form nee- is associated not only with second person plural subject but also with third person plural subject. This lack of formal differences in the form of nee- associated with the first, second and third person singular, for instance, is a possible source of ambiguity among these person distinctions in the event of the dropping of the substantive subject in finite declarative sentences. 


\begin{tabular}{|c|c|c|c|}
\hline eená & née & -rú & 'You (pl.) have come. \\
\hline $2 \mathrm{plS}$ & 2pl.PRES PERF & -come & \\
\hline eedí & née & -rú & 'They have come.' \\
\hline $3 \mathrm{plS}$ & 3pl.PRES PERF & -come & \\
\hline
\end{tabular}

Example (1) illustrates the use of these pronouns in subject position.

3.1.2. Object pronouns. Object pronouns occur after the verb, and function as the object of a sentence. These pronouns, in their isolation forms, are identical with their subject counterparts both segmentally and tonally. Object pronouns are also consistent in their tone patterns when they are used in a sentence, except that in certain grammatical contexts the tone patterns of the ones that refer to first and second person singular tend to vary. The forms of object pronouns are given in Table 3:

\begin{tabular}{cccc} 
Table 3: & \multicolumn{3}{c}{ Forms of Object Pronouns } \\
Singular & $1^{\text {st }}$ & áámí & 'me' \\
& $2^{\text {nd }}$ & ádná $^{\prime}$ & 'you' \\
& $3^{\text {rd }}$ & od'́ & 'her/him/it'
\end{tabular}

$\begin{array}{clll}\text { Plural } & 1^{\text {st }} & \text { eziró } & \text { 'us' (incl.) } \\ & & \text { ézóór } & \text { 'us' (excl.) } \\ & 2^{\text {nd }} & \text { eenó } & \text { 'you' } \\ & 3^{\text {rd }} & \text { eedí } & \text { 'them' }\end{array}$

Example (2) illustrates the use of these pronouns in object position:

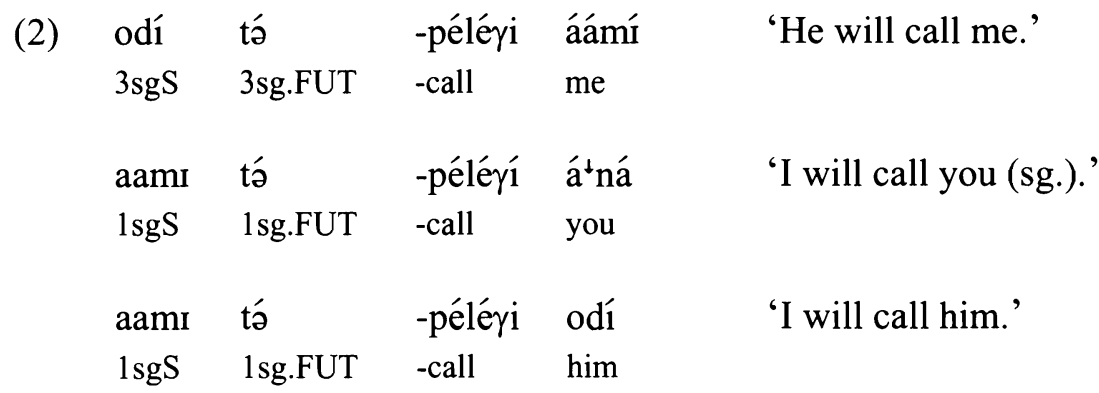




\begin{tabular}{|c|c|c|c|c|}
\hline ána & tá & -pélé $\gamma \mathbf{i}$ & ézóว́r & 'You (sg.) will call us.' \\
\hline $2 \mathrm{sgS}$ & 2sg.FUT & -call & us & \\
\hline ezirá & tó & -pélé $\gamma \mathrm{i}$ & eedí & 'We (incl.) will call them.' \\
\hline $1 \mathrm{plS}$ & 1pl.PST & - see & them & \\
\hline ezəər & tó & -pélé $\gamma i$ & eená & 'We (excl.) will call you (pl.).' \\
\hline $1 \mathrm{plS}$ & 1pl.FUT & -call & you & \\
\hline
\end{tabular}

Example (3) shows the variations in the tone patterns of the first and second person singular object pronouns in conditional constructions:

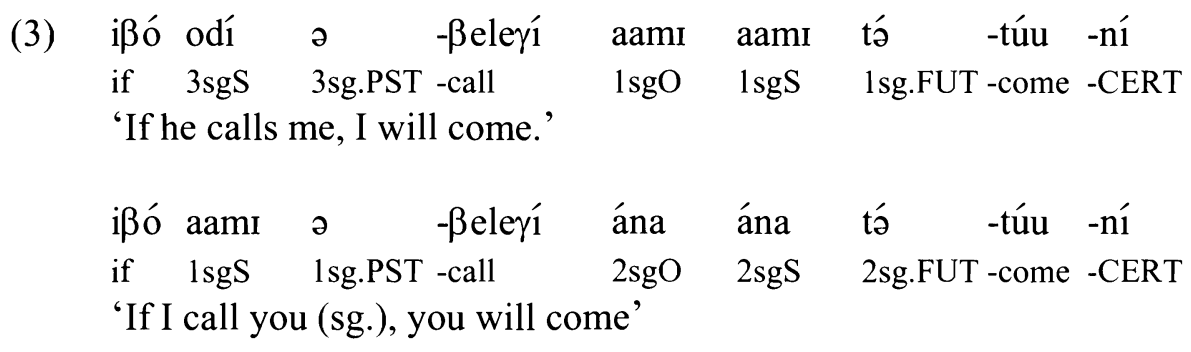

In (3), the tone of first person singular is low on all moras, while that of the second person singular is high on the first mora but low on the second mora.

3.1.3. Possessive pronouns. One of the ways of expressing the idea of ownership in Odual is by the use of possessive pronouns (cf. Tsunoda 1997: 17). These pronouns follow the possessed noun or possessee. Possessive constructions in Odual are verbless constructions. Possessive pronouns, except the one that refers to second person singular, are like their subject and object counterparts with respect to their segmental composition, but the form that refers to second person singular is ónútmá 'your'. Tonally, the forms referring to third person singular, first person plural inclusive and second and third person plural are somewhat different from their subject and object counterparts. The third person singular has a high-high tone pattern; the first person plural inclusive has a high-high-downstepped-high tone pattern; the second person plural has a low-high-downstepped-high tone pattern, while the third person plural has a low-high-high tone pattern. The forms of object pronouns are given in Table 4. 
Table 4: Forms of Possessive Pronouns

\begin{tabular}{|c|c|c|c|}
\hline Singular & $\begin{array}{l}1^{\text {st }} \\
2^{\text {nd }} \\
3^{\text {rd }}\end{array}$ & $\begin{array}{l}\text { áámí } \\
\text { ónútmó } \\
\text { ódí }\end{array}$ & $\begin{array}{l}\text { 'my' } \\
\text { ‘your' } \\
\text { 'her/his/its' }\end{array}$ \\
\hline Plural & $1^{\text {st }}$ & $\begin{array}{l}\text { ézírtó } \\
\text { ézáór }\end{array}$ & $\begin{array}{l}\text { 'our' (incl.) } \\
\text { 'our' (excl.) }\end{array}$ \\
\hline & $\begin{array}{l}2^{\text {nd }} \\
3^{\text {rd }}\end{array}$ & $\begin{array}{l}\text { ééná } \\
\text { eédí }\end{array}$ & $\begin{array}{l}\text { 'your' } \\
\text { 'their', }\end{array}$ \\
\hline
\end{tabular}

Example (4) illustrates the use of these pronouns in possessive noun phrases:

\begin{tabular}{|c|c|c|}
\hline 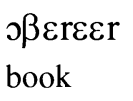 & $\begin{array}{l}\text { amí } \\
1 \text { sg.POSS }\end{array}$ & 'my book' \\
\hline 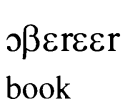 & $\begin{array}{l}\text { onúlmá } \\
\text { 2sg.POSS }\end{array}$ & 'your (sg.) book' \\
\hline 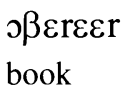 & $\begin{array}{l}\text { ezí `'ró } \\
\text { 1pl.POSS }\end{array}$ & 'our (incl.) book' \\
\hline 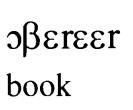 & $\begin{array}{l}\text { ezáár } \\
\text { Ipl.POSS }\end{array}$ & 'our (excl.) book' \\
\hline 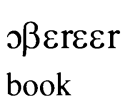 & $\begin{array}{l}\text { eé`ná } \\
\text { 2pl.POSS }\end{array}$ & 'your (pl.) book' \\
\hline 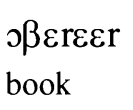 & $\begin{array}{l}\text { ódí } \\
\text { 3sg.POSS }\end{array}$ & 'his book' \\
\hline 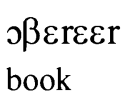 & $\begin{array}{l}\text { eédí } \\
\text { 2pl.POSS }\end{array}$ & 'their book' \\
\hline
\end{tabular}

A look at example (4) reveals that the form of the possessive pronoun referring to first person singular is altered both segmentally and tonally. Specifically, it is observed that one of the identical vowels gets deleted and the tone pattern gets changed from high-high-high to low-high. It is also observed that the 
initial high tone of the second person singular pronoun and that of the first, second and third person plural pronouns gets deleted in genitive constructions.

The possessive forms in (4) are the forms used as determiners. When these possessives are used as nominals, they are preceded by the morpheme olo, meaning belonging to, as (5) shows:

\begin{tabular}{|c|c|c|c|c|}
\hline 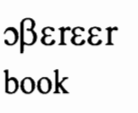 & $\begin{array}{l}\text { oóßo } \\
\text { sg.PROX }\end{array}$ & $\begin{array}{l}\text { olo } \\
\text { POSS }\end{array}$ & $\begin{array}{l}\text { amí } \\
\text { 1sg.POSS }\end{array}$ & 'This book is mine.' \\
\hline 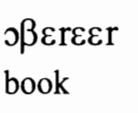 & $\begin{array}{l}\text { oóßo } \\
\text { sg.PROX }\end{array}$ & $\begin{array}{l}\text { olo } \\
\text { POSS }\end{array}$ & $\begin{array}{l}\text { onútmá } \\
\text { 2sg.POSS }\end{array}$ & 'This book is yours (sg.).' \\
\hline 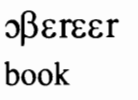 & $\begin{array}{l}\text { oóßo } \\
\text { sg.PROX }\end{array}$ & $\begin{array}{l}\text { olo } \\
\text { POSS }\end{array}$ & $\begin{array}{l}\text { ódí } \\
\text { 3sg.POSS }\end{array}$ & 'This book is his.' \\
\hline 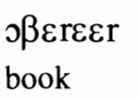 & $\begin{array}{l}\text { oóßo } \\
\text { sg.PROX }\end{array}$ & $\begin{array}{l}\text { olo } \\
\text { POSS }\end{array}$ & $\begin{array}{l}\text { ezí ‘rá } \\
\text { lpl.POSS }\end{array}$ & 'This book is ours (incl.).' \\
\hline 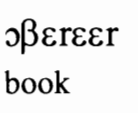 & $\begin{array}{l}\text { oóßo } \\
\text { sg.PROX }\end{array}$ & $\begin{array}{l}\text { olo } \\
\text { POSS }\end{array}$ & $\begin{array}{l}\text { ezáár } \\
\text { lpl.POSS }\end{array}$ & 'This book is ours (excl.).' \\
\hline $\begin{array}{l}\text { ¡ } \beta \varepsilon \varepsilon \varepsilon r \\
\text { book }\end{array}$ & $\begin{array}{l}\text { oóßo } \\
\text { sg.PROX }\end{array}$ & $\begin{array}{l}\text { olo } \\
\text { POSS }\end{array}$ & $\begin{array}{l}\text { (e)ét’ná } \\
\text { 2pl.POSS }\end{array}$ & 'This book is yours (pl.).' \\
\hline 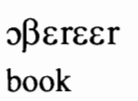 & $\begin{array}{l}\text { oóßo } \\
\text { sg.PROX }\end{array}$ & $\begin{array}{l}\text { olo } \\
\text { POSS }\end{array}$ & $\begin{array}{l}\text { eédí } \\
\text { 3pl.POSS }\end{array}$ & 'This book is theirs' \\
\hline
\end{tabular}

A summary of the forms of personal pronouns in Odual is given in Table 5. 
Table 5: Summary of Odual Personal Pronouns

Sg. $\quad 1^{\text {st }}$

$2^{\text {nd }}$
$3^{\text {rd }}$

\section{Subject}

Pl. $\quad 1^{\text {st }}$

$2^{\text {nd }}$

$3^{\text {rd }}$ áámí 'I'

áłná 'you'

odí' 's/he/it'

eziró 'we' (incl.)

ézáŕr 'we' (excl.)

eená 'you'

eedí 'they'
Object

áámí 'me'

áłná 'you'

odí 'her/him/it'

eziró 'us' (incl.)

ézárór 'us' (excl.)

eená 'you'

eedí 'them'
Possessive

áámí 'my'

ónútmá 'your'

ódí 'her/his/its'

ézírłá ‘our' (incl.)

ézáór 'our' (excl.)

eétná 'your'

eédí 'their'

3.2. Reflexive pronouns. Reflexivity in Odual is expressed by a genitive construction which involves a combination of a noun alarr 'self' and any of the possessive pronouns discussed in 3.1.3. The pronouns always follow the noun as (6) shows:
$\begin{array}{ll}\text { (6) ələər } & \text { amí } \\ \text { self } & 1 \text { sg.POSS }\end{array}$
'myself'
ələər onútmá
'yourself'
self 2 sg.POSS
aləər ódí
'himself/herself'
self $\quad 3$ sg.POSS
$\begin{array}{ll}\text { əsiləər } & \text { ezí 'ró } \\ \text { selves } & 1 \text { pl.POSS }\end{array}$
$\begin{array}{lll}\text { əsiləər } & \text { ezäár } & \text { 'ourselves' (excl.) } \\ \text { selves } & 1 \text { pl.POSS } & \end{array}$
əsiləor eé`nó 'yourselves'
selves 2pl.POSS
əsiləər eédí 'themselves'
selves 3pl.POSS 
Example (7) illustrates how the noun + possessive pronoun combination expresses reflexivity in a sentence:

$\begin{array}{lllll}\text { aami U -mó Uon } & \mathrm{m} & \text {-ələər } & \text { amí } \\ \text { 1sgS 1sg.PST -hear } & \text { OM } & \text {-self } & 1 \text { sg.POSS } \\ \text { 'I heard myself.' } & & & \end{array}$

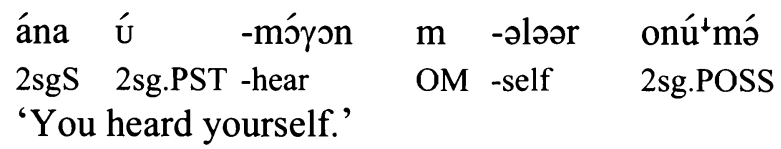

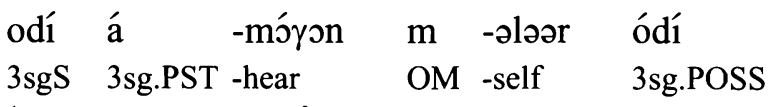

'He heard himself.'

\begin{tabular}{|c|c|c|c|c|}
\hline eziró & -mว́үวn & $\mathrm{m}$ & -əsiləər ${ }^{7}$ & ezí 'ró \\
\hline $1 \mathrm{plS}$ & 1pl.PST -hear & OM & -selves & 1pl.POSS \\
\hline
\end{tabular}

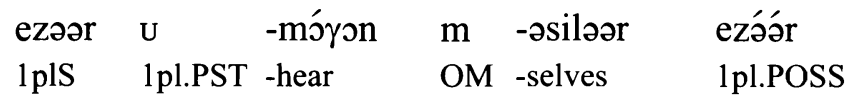

'We (excl.) heard ourselves.'

\begin{tabular}{|c|c|c|c|c|c|}
\hline eeñ́ & Í & -mó & $\mathrm{m}$ & -əsiləər & eétnó \\
\hline $2 \mathrm{plS}$ & 2pl.PST & -hear & OM & -selves & 2pl.POSS \\
\hline
\end{tabular}

$\begin{array}{lllll}\text { eedi Í } & \text { I -móyon } & \text { m } & \text {-əsiləər } & \text { eédí } \\ \text { 3plS 3pl.PST } & \text {-hear } & \text { OM } & \text {-selves } & \text { 3pl.POSS } \\ \text { 'They heard themselves.' } & & & \end{array}$

${ }^{7}$ Odual is a noun class language. This means that nouns are classified into genders on the basis of semantically determined (singular, plural and single class) prefixes attached to the noun stem. For this reason, many nouns such as á-láar 'body/self' (sg.) and ásí-láar 'bodies/selves' (pl.) have a singular and a plural form marked by alternating prefixes. The difference between the singular '́-láor 'body' and plural ásí-láor 'bodies' (pl.) in these examples results from the fact as an anaphor, the noun + possessive pronoun changes its form to reflect the antecedent. The form á-lár 'body/self" with a singular possessive pronoun is used when a singular antecedent is involved, while the form ásí-lár 'bodies/selves' with a plural possessive pronoun is used when a plural antecedent is involved. 
In reflexives constructions with a plural subject, the noun alarr 'selves' changes its form to asilaar 'selves' to reflect the number of discourse participants.

3.2.1. Interrogative pronouns. Six interrogative pronouns can be identified in Odual. These pronouns, unlike the personal pronouns, do not encode in themselves the grammatical categories of person, number or case. Some of these pronouns, however, change their tones in grammatical contexts. The forms (and meanings) of these pronouns, as given in Table 6, are the forms they take when they are said in isolation.

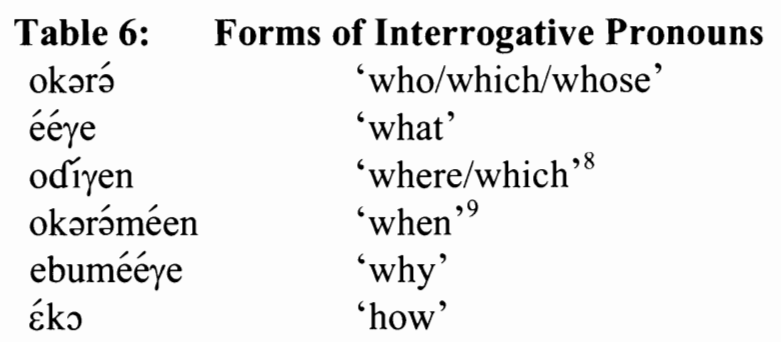

Examples (8) - (10) illustrate the use of these pronouns in grammatical contexts:
okərá áəj
'Who?'
which person
okərá ว́ß́́rદer
'Which book?'
which book

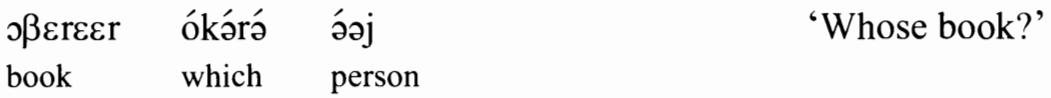

When okara' has the meaning 'who' or 'which', it precedes the noun it questions, as in (8) but when it has the meaning 'whose' it is sandwiched between two nouns. In this position, the noun that follows okará always refers to an entity that has human attributes. Consider the interrogative pronouns in (9).

\footnotetext{
8 The form odi' yen cannot be used to mean 'whose.'

9 The form okəráméen is a combination of okərá 'which' and amen 'time.'
} 
(9)

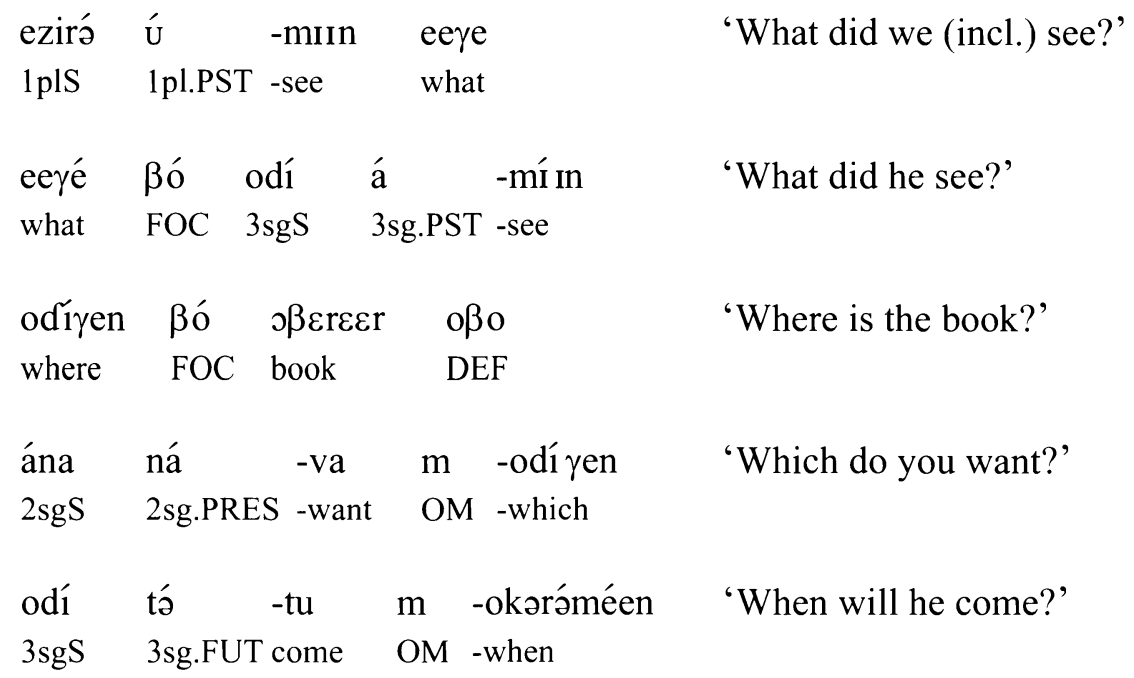

The interrogative pronoun ééye 'what' in (9) can occur in both sentence-initial and sentence-final positions. The tone pattern of this pronoun is contextually determined. In sentence-final position, the tone pattern of the pronoun is low on all moras, whereas in sentence-initial position the pronoun has an overall low-high tone pattern. When the interrogative pronouns odiyen 'where/which' and okaráméen 'when' occur post-verbally, they are preceded by the object marker $m$-.

Finally, let us consider the interrogative pronouns in (10):

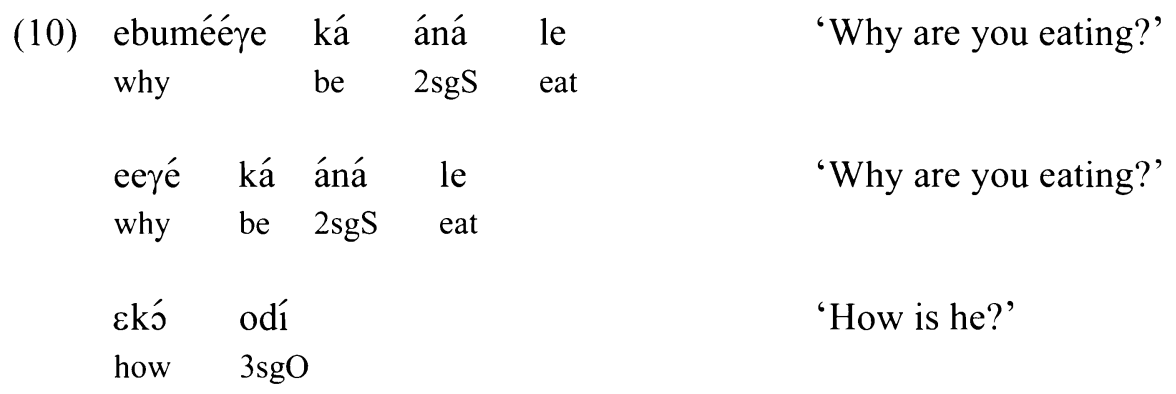

The forms ebuméére and eejé in (10) can be used interchangeably to mean 'why.'

3.2.2. Demonstrative pronouns. There are four demonstrative pronouns in Odual, as seen in Table 7. These pronouns very often require the speaker to indicate the relative position or location of an entity or entities by pointing to the en- 
tity or entities. According to Börjars \& Burridge (2001:59), demonstrative pronouns 'typically have to do with the orientational features of language'.

The four demonstrative pronouns in Odual are divided into two proximal demonstratives, ooßó 'this' and iißá 'these' (referring respectively to one or more than entity that is/are close to the speaker), and two distal demonstratives, opó 'that' and ip' 'those' (referring respectively to one or more than one entity that is/are far from the speaker). These demonstrative pronouns intersect with number, singular and plural. The singular demonstratives are ooßó 'this' and opó 'that', while the plural demonstratives are iißá 'these' and ipá 'those.'

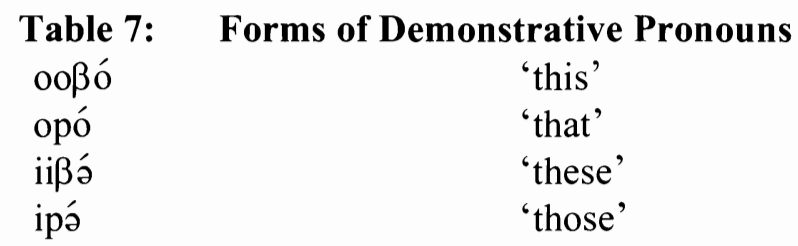

In isolation, demonstrative pronouns have an overall low-high tone pattern. This tone pattern is, however, not maintained when demonstratives co-occur with other words. Segmentally, proximal demonstratives are similar, as both are trimoraic and begin with a sequence of two identical vowel prefixes oo- and $i i$-, while the distal demonstratives are also similar, as both are bimoraic and begin with single vowel prefixes $o$ - and $i$-. Example (11) illustrates demonstrative pronouns in noun phrases:
$\begin{array}{lll}\text { (11) out } & \text { oóßó } \\ \text { house } & \text { sg.PROX }\end{array}$
'this house'
ərutu iíßə
'these houses'
houses pl.PROX
$\begin{array}{ll}\text { out } & \text { ópó } \\ \text { house } & \text { sg.DIST }\end{array}$
ərutu ípá
houses pl.DIST
'that house'
'those houses'

Demonstratives agree in number with nouns in noun + demonstrative constructions. In these constructions, demonstratives follow the nouns they modify. 
Let us consider example (12), where demonstrative pronouns occur in sentence-initial position.

\begin{tabular}{|c|c|c|c|}
\hline $\begin{array}{l}\text { ooßó } \\
\text { sg.PROX }\end{array}$ & $\begin{array}{l}\text { э } \beta \varepsilon \mathrm{r} \varepsilon \varepsilon \mathrm{r} \\
\text { book }\end{array}$ & $\begin{array}{l}\text { amí } \\
1 \text { sg.POSS }\end{array}$ & 'This is my book.' \\
\hline $\begin{array}{l}\text { ooßó } \\
\text { sg.PROX }\end{array}$ & 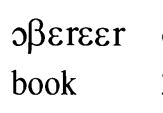 & $\begin{array}{l}\text { onútmó } \\
\text { 2sg.POSS }\end{array}$ & 'This is your (sg.) book.' \\
\hline $\begin{array}{l}\text { ooßó } \\
\text { sg.PROX }\end{array}$ & 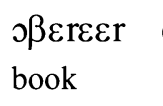 & $\begin{array}{l}\text { ezí ‘ró } \\
\text { lpl.POSS }\end{array}$ & 'This is our (incl.) book.' \\
\hline $\begin{array}{l}\text { ooßó } \\
\text { sg.PROX }\end{array}$ & 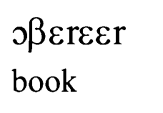 & $\begin{array}{l}\text { ezáór } \\
\text { lpl.POSS }\end{array}$ & 'This is our (excl.) book.' \\
\hline $\begin{array}{l}\text { ooßó } \\
\text { sg.PROX }\end{array}$ & 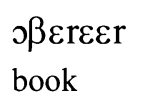 & $\begin{array}{l}\text { eé 'nó } \\
\text { 2pl.POSS }\end{array}$ & 'This is your (pl.) book.' \\
\hline $\begin{array}{l}\text { ooßó } \\
\text { sg.PROX }\end{array}$ & 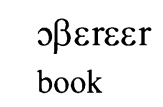 & $\begin{array}{l}\text { ódí } \\
\text { 3sg.POSS }\end{array}$ & 'This is his book.' \\
\hline $\begin{array}{l}\text { ooßó } \\
\text { sg.PROX }\end{array}$ & 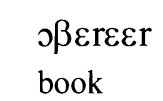 & $\begin{array}{l}\text { eé dí } \\
3 \text { pl.POSS }\end{array}$ & 'This is their book.' \\
\hline
\end{tabular}

When demonstratives occur in sentence-initial position, they function no longer as determiners but as independent demonstratives, capable of serving as the subject of the sentence. In sentence-initial position, demonstratives retain their inherent tones.

3.2.3. Indefinite pronouns. Indefinite pronouns in Odual are mostly compound in nature. In other words, they involve more than one morpheme, as in (13). Some indefinite pronouns are cases of reduplication: 

$\begin{array}{ll}\text { (13) ojiı́n } & \text { á`ój } \\ \text { one } & \text { person }\end{array}$
əój oló
'someone'
person none
oló $m$-étśs 'nowhere'
none $\mathrm{OM}$-place
$\begin{array}{lll}\begin{array}{l}\text { kə-ə́əj } \\ \text { every-person }\end{array} & \begin{array}{l}\text { kə-ว́ð’j } \\ \text { every-person }\end{array} & \text { 'everybody' }\end{array}$

$\begin{array}{lll}\text { késí } & \text { késí } & \text { 'everywhere' } \\ \text { kə-ésí } & \text { kə-ésí } & \\ \text { every-place } & \text { every-place } & \end{array}$

In (13) oniĺn áł áj expresses an affirmative meaning, making a personal reference; aáj oló and oló $m$-étsí express a negative meaning, making a personal and non-personal reference respectively, while kə-áaj kə-átáj and késí késí express a universal meaning, referring to human beings and locations respectively (cf. Ndimele 1996: 55f).

\section{Word Order.}

Odual has a basic subject-verb-object (SVO) word order in simple clauses. In this word order, the subject is followed by the verb, which in turn is followed by the object, as seen in (14):
(14) edirotu
Edighotu
á -mín
ว’ ’’bádí
'Edighotu saw an iguana.'
$\mathrm{S}$
PAST -see iguana
$\mathrm{O}$

The SVO word order in Odual is consistent with the basic word order in Cross River languages (cf. Faraclas 1989: 329).

4.1. Order of Pronouns. In this subsection, we shall discuss the order of pronouns in Odual in relation to other words in the context of the basic word order in simple clauses. Specifically, we shall discuss the relative position of Odual pro- 
nouns to other constituents in the noun phrase (NP), since many of these pronouns are modifiers.

Let us consider the following NP constructions: in (15), the article follows the noun in the noun-article construction.
(15) o-rej oßo
'the tree'
tree the

In (16), however, the modifier precedes the noun in the modifier-noun construction.
(16) o-boóbí ว́əj
beautiful
man/person

'beautiful man/person'

The pattern observed in (16) is an exception to the typological, basic word order, as it deviates from the head-initial nature of constructions expected of SVO languages seen in (14)

Let us consider the position of pronominal modifiers in (17):
a. $\beta \varepsilon r \varepsilon \varepsilon r \quad$ eédí
'their book'
book
2pl.POSS
b. $\beta \varepsilon r \varepsilon \varepsilon r$
book
oóßo olo
amí
'This book is mine.'
sg.PROX
POSS
1sg.POSS

In (17a), the possessive pronoun follows the modified noun. This is typologically consistent with the basic word order in simple clauses in the language. In verbless constructions featuring a demonstrative and a possessive pronoun, such as (17b), the possessive follows the demonstrative pronoun.

Consider the reflexive construction in (18).
(18)

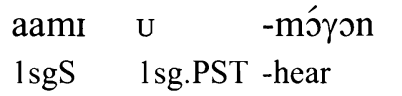
$\mathrm{m}$-ələər amí
'I heard myself.'
$\mathrm{OM}$-self 1sg.POSS

Two observations can be made about (18). First, the reflexive pronoun follows the verb thereby conforming to the basic word order. Second, the possessive pronoun that combines with the noun to form the reflexive follows the noun. This is so because the reflexive itself is a genitive construction, like (17a). 
Furthermore, let us consider the position of the demonstrative pronoun in relation to the noun in (19).
a. otu
oóßó
'this house'
house
sg.PROX

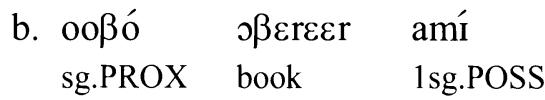
'This is my book.'

Demonstrative pronouns follow the modified noun in the noun-demonstrative construction, like possessives in (19a). This is consistent with the basic word order in simple clauses. The word order in which demonstrative pronouns precede the noun, as in (19b), is not basic. Such non-basic word order occurs as a result of some degree of prominence given to the demonstrative. Demonstratives that precede the noun are emphatic and function as subject/topic, since there is a correlation between initial/subject position and communicative prominence.

Let us consider interrogative pronouns with regard to word order in the NP and then with regard to the basic SVO word order in simple clauses:
a. okərá á aj
'who?'
which person

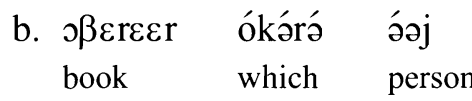
'whose book?'

The semantics of okará determines its position relative to the noun it questions. It is observed that when the pronoun questions the identity of someone, it precedes the noun it questions but when the pronoun seeks to establish the ownership of something, together with the noun áj, it follows the noun it questions. What this means is that (20b) is consistent with the word order in the NP, which to a large extent is a reflection of the basic word order in the simple clause, whereas (20a) is not. However, if we reason that the interrogative pronoun and the following noun in (20a) constitute a single unit, on the basis of the fact that they both occur after the noun $\supset \beta \varepsilon r \varepsilon \varepsilon r$ 'book' in (20b), then there will be no case of inconsistency of (20a) with the word order in the NP and by extension with the basic word order in the minimal clause.

Now, let us consider the other interrogative pronouns. 
$(21)$

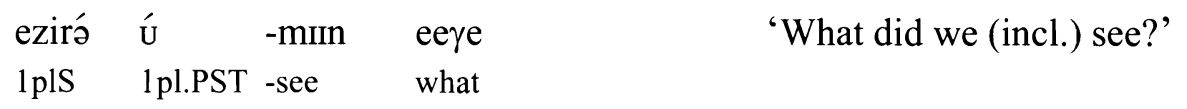
eejé ßó eziró ú -mínn 'What did we (incl.) see?' what FOC 1plS 1pl.PST see

$\begin{array}{lllll}\text { ána } & \text { ná } & \text {-va } & \mathrm{m} & \text {-odíren }\end{array}$

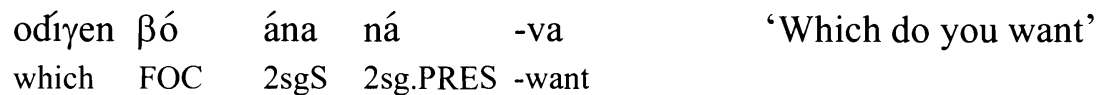
$\begin{array}{lllll}\text { odí tó } & \text {-tu } & \mathrm{m} & \text {-okəróméen } & \text { 'When will he come?' } \\ \text { 3sgS } & \text { 3sg.FUT come } & \text { OM } & \text {-when }\end{array}$ okəróméen ßó odi tó -tu 'When will he come' when FOC 3sgS 3sg.FUT-come

A general remark that can be made regarding the interrogative pronouns such as

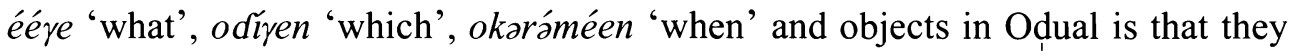
can optionally be moved to the front of the sentence. The occurrence of these pronouns in sentence-initial position serves a discourse function. When they are fronted, they are followed by the focus marker $\beta o ́$.

Finally, let us consider indefinite pronouns:
(22) opiín átój
'someone'
one person
əáj oló
'nobody'
person none
oló $\quad \mathrm{m} \quad-\mathrm{e}^{+} \mathrm{si}$
'nowhere'
none $\mathrm{OM}$-place

Indefinite pronouns are themselves phrases with varying word orders. The word order in the pronoun meaning 'someone' is that of numeral + noun, where the numeral precedes the noun. The word order in the pronoun meaning 'nobody' is that of noun + (negative) pronoun, where the pronoun follows the noun. The word 
order in the pronoun meaning 'nowhere' is that of (negative) pronoun + noun, where the pronoun precedes the noun. Of these varying word orders, it is only the one in the pronoun meaning 'nobody' that is consistent with the basic word order. $^{10}$

From the preceding discussion of the pronominal system of Odual it is observed that Odual is, to a large extent, typologically consistent in the sense that most of its pronouns follow the modified noun in NP constructions, which in turn are consistent with the basic SVO word order in simple clauses in the language. According to Givón (1984: 189), “...if it [a language:EK] has the order VERBOBJECT (VO) in simple clauses, it should have the order NOUN-MODIFIER (N-M) in noun phrases". The Odual case supports Givón's typological prediction as regards consistency in word order in NPs with the basic word order in simple clauses in a given language.

\section{Conclusion.}

We have examined the pronominal system of Odual. One of the notable observations made is that Odual maintains an inclusive/exclusive distinction in its pronominal system - a distinction that is overtly expressed in the forms of first person plural personal pronouns. It is further observed that personal pronouns are to a large extent similar in their segmental and tonal composition. Reflexivity is observed to be marked by a combination of the noun meaning 'self' and a possessive pronoun. The noun meaning 'self' varies in form depending on the singularity or plurality of the antecedent, while the possessive pronoun varies based on the number and person feature of the antecedent. It is also noted that tense/aspect markers in Odual show partial agreement for person and number, given that in some cases they do not have distinct forms that reflect the differences in the forms of pronouns occasioned by differences in person and number. Furthermore, it is established that the basic word order in Odual simple clauses is SVO, and that word order in NPs to a large extent is typologically consistent with the basic word order, as many of the pronouns that function as modifiers follow the noun they modify. The positional relationship of pronouns with other elements in the NP in Odual lends support to Givon's typological prediction that word order in NPs should reflect the basic word order in simple clauses.

${ }^{10} \mathrm{I}$ do not have additional data to say more than this about indefinite pronouns. 


\section{References}

Börjars, Kersti \& Kate Burridge. 2001. Introducing English Grammar. London and New York: Arnold and Oxford University Press.

Comson, Emmanuel E. 1987. The Phonology of Odual. B.A. long essay: University of Port Harcourt.

Deterding, David H. \& Gloria R. Poedjosoedarmo. 2001. The Grammar of English: Morphology and Syntax for English Teachers in Southeast Asia. Singapore: Prentice Hall.

Faraclas, Nicholas G. 1989. “Cross River.” The Niger-Congo Languages, ed. by John Bendor-Samuel. Lanham: University Press of America, Inc. Pp. 378-399.

Gardner, Ian D. 1975. Odual/English Word List. Trial Edition. Jos: Institute of Linguistics.

Gardner, Ian, Amelia Gardner \& Martin Abigo. 1974. Reading and Writing Odual. Ibadan and Port Harcourt: Rivers Readers Project.

Givón, T. 1984. Syntax: A Functional Typological Introduction I. Amsterdam/Philadelphia: John Benjamins Publishing Company.

Kari, Ethelbert E. 2006. Noun Class Vestiges in Odual. Paper presented at the 20th Conference of the Linguistic Association of Nigeria (CLAN) held at Sheda-Abuja from November 13 - 17, 2006.

Lyons, John. 1968. Introduction to Theoretical Linguistics. Cambridge: Cambridge University Press.

Madumere, Rosemary O. 2006. Verb Morphology of Odual. B.A. long essay, University of Port Harcourt. 
Mutaka, Ngessimo \& Pius N. Tamanji. 2000. Introduction to African Linguistics. Muenchen: Lincom Europa.

Ndimele, Ozo-mekuri. 1996. An Advanced English Grammar and Usage. Revised edition. Aba: National Institute for Nigerian Languages.

Tsunoda, Tasaku. 1997. "Expression of Possession in Warrungu of Australia". Studies in Possessive Expressions, ed. by Tooru Hayasi \& Peri Bhaskararao. Tokyo: Institute for the Study of Languages and Cultures of Asia and Africa. Pp. 11-115.

Dept. of Linguistics \& Communication Studies

Faculty of Humanities

University of Port Harcourt

P.M.B. 5323, Port Harcourt Nigeria

eekari99@yahoo.com [received January 15, 2007 accepted February 27, 2007] 
